\title{
Article
}

\section{Photocatalytic degradation of bisphenol A using Ti-substituted hydroxyapatite}

\author{
Qian Li a, Xiang Feng a, Xiao Zhang a, Han Song a, Jianwei Zhang a, Jing Shang a,*, Weiling Sun a, \\ Tong Zhu ${ }^{a}$, Masato Wakamura ${ }^{b}$, Mineharu Tsukada ${ }^{b}$, Yingliang Lu ${ }^{c}$ \\ a College of Environmental Sciences and Engineering, Peking University, Beijing 100871, China \\ ${ }^{\mathrm{b}}$ Environment and Energy Research Center, Fujitsu Laboratories Limited, Atsugi, Japan \\ c Fujitsu Research and Development Center Company Limited, Beijing 100025, China
}

\section{A R T I C L E I N F O}

\section{Article history:}

Received 22 July 2013

Accepted 11 September 2013

Published 20 January 2014

\section{Keywords:}

Titanium-substituted hydroxyapatite

Photocatalysis

Bisphenol A

Adsorption

Titanium dioxide

\begin{abstract}
A B S T R A C T
Ti-substituted hydroxyapatite (TiHAP) is a new photocatalyst with high adsorption capacity and photocatalytic activity. The morphology and structure of TiHAP were characterized using transmission electron microscopy, X-ray diffraction, ultraviolet-visible spectrophotometry, and the zeta potential. The adsorption and photocatalytic degradation of bisphenol A (BPA, an environmental endocrine disrupting chemical) over TiHAP and $\mathrm{P} 25 \mathrm{TiO}_{2}$ photocatalysts were studied using liquid chromatography-mass spectrometry. The influences of fulvic acid and $\mathrm{Fe}^{3+}$ ions on the BPA degradtion rate were analyzed. The adsorption of $\mathrm{BPA}$ on $\mathrm{TiHAP}$ and $\mathrm{TiO}_{2}$ obeyed the Langmuir adsorption equation. TiHAP exhibited much higher adsorption capacity and photocatalytic degradation activity of $\mathrm{BPA}$ than $\mathrm{TiO}_{2}$. Fulvic acid and $\mathrm{Fe}^{3+}$ showed different effects on the photocatalytic activity of Ti$\mathrm{HAP}$ and $\mathrm{TiO}_{2}$ films. These were explained by band structure theory, the electron transfer path, and optical absorption capacity. The results are useful for the application of TiHAP in the photocatalytic degradation of environmental endocrine disrupting chemicals.
\end{abstract}

(C) 2014, Dalian Institute of Chemical Physics, Chinese Academy of Sciences. Published by Elsevier B.V. All rights reserved.

\section{Introduction}

Bisphenol A (BPA) is a common industrial raw material widely used in the manufacturing of epoxy resin, polycarbonate resin, and polystyrene resin [1]. If the end products, that is, plastic products, food containers, medical supplies, etc., are directly discharged into rivers and seas or discharged with the waste effluent, BPA will be released into the environment, especially an aquatic environment [2]. In recent years, BPA has been frequently detected in water and drinking water all over the world [3]. For example, a research report in Germany gave the BPA concentration in surface water in 1997 as $0.5-410$
ng/L [4]. From 2002 to 2003, BPA detected in drinking water sources in Hangzhou was 0.33-25.09 ng/L [5]. In 2002, an investigation of a typical sewage treatment plant in Beijing detected 30 kinds of endocrine disrupters. Among these, the BPA concentration was the highest at $0.825 \mathrm{mg} / \mathrm{L}$ [6]. China's Drinking Water Health Standards (GB 5749-2006) regulates the limiting value of BPA to be less than $0.01 \mathrm{mg} / \mathrm{L}$. BPA is an important environmental endocrine disrupting chemical. It behaves as an estrogen in influencing physiological functions of organisms. Even a very small dose of BPA can lead to female precocious puberty, sperm decrease, prostatic hypertrophy and it has certain embryotoxicity and teratogenicity. By direct con-

\footnotetext{
*Corresponding author. Tel: +86-10-62759716; E-mail: shangjing@pku.edu.cn

This work was supported by the Fujitsu Laboratories Limited Foundation (k120400), the Beijing Natural Science Foundation (8132035), and the National Natural Science Foundation of China $(21277004,21190051,41121004)$.

DOI: 10.1016/S1872-2067(12)60709-8 | http://www.sciencedirect.com/science/journal/18722067 | Chin. J. Catal., Vol. 35, No. 1, January 2014
} 
tact or accumulation through the biological chain, BPA can enter the human body, which would lead to endocrine imbalance and disruption of the metabolic process. It also influences the immunity systems of infants and can cause male infertility and cancer [7]. Therefore, it is essential to remove BPA from the aqueous phase. Conventional BPA removal methods include biological, physical, and chemical methods. The chemical methods include Fenton oxidation [8], ultraviolet oxidation [9], $\mathrm{H}_{2} \mathrm{O}_{2}$ oxidation [10], oxychlorination [11], and photocatalytic oxidation treatment [12]. Simple Fenton, ultraviolet or $\mathrm{H}_{2} \mathrm{O}_{2}$ oxidation perform poorly in the removal of BPA, and the combination of several approaches are needed. For example, the incomplete oxidative degradation of BPA during oxychlorination process produces byproducts with stronger endocrine disruption effects [13]. Therefore, it is essential to find ways to more effectively remove these endocrine disrupters.

As an advanced oxidation technology, photocatalysis can remove organic and inorganic pollutants. It has advantages such as high catalytic efficiency, complete oxidation, and low energy consumption compared to the conventional technologies. In recent years, there have been many studies on the photocatalytic degradation of $\mathrm{BPA}$ by $\mathrm{TiO}_{2}$ under ultraviolet irradiation, which verified that photocatalysis can completely oxidize BPA to $\mathrm{CO}_{2}$ and $\mathrm{H}_{2} \mathrm{O}$ with no secondary pollutants [14]. The estrogenic activity could be reduced to less than $10 \%$ of the original solution [14]. $\mathrm{TiO}_{2}, \mathrm{H}_{2} \mathrm{O}_{2}$, and ultrasound can have synergistic effects [15]. The photocatalytic efficiency of 3D mesoporous $\mathrm{TiO}_{2}$ was higher than that of commercial P25 $\mathrm{TiO}_{2}$ [16]. Kuo et al [17] explored the effects of $\mathrm{pH}$ and polyethylene glycol on the photocatalytic degradation of $\mathrm{BPA}$ by $\mathrm{TiO}_{2}$ under visible light. The photocatalytic degradation of BPA often needs an additive, such as $\mathrm{H}_{2} \mathrm{O}_{2}$ [18]. In order to improve catalytic efficiency, it is necessary to develop new and more efficient photocatalysts.

Ti-substituted hydroxyapatite (TiHAP) is a new photocatalyst. It is a crystal with $\mathrm{Ti}^{4+}$ replacing part of the $\mathrm{Ca}^{2+}$ in hydroxyapatite (HAP). HAP is a common medical material used in fixing tooth and bone tissues. The molecular formula of HAP is $\mathrm{Ca}_{10}\left(\mathrm{PO}_{4}\right)_{6}(\mathrm{OH})_{2}$. The $\mathrm{Ca}^{2+}$ ion can be replaced by other positive ions. Kandori et al [19] used metal ions such as $\mathrm{Al}^{3+}, \mathrm{La}^{3+}$, and $\mathrm{Fe}^{3+}$ to replace $\mathrm{Ca}^{2+}$ in HAP and investigated the adsorption capacity of the modified HAP for proteins. Wakamura et al. [20] synthesized TiHAP, which exhibited high photocatalytic activity under ultraviolet light. Tsukada et al. [21] evaluated the band gap and electronic structure of TiHAP both experimentally and theoretically. TiHAP has an adsorption capacity that is superior to $\mathrm{TiO}_{2}$ [22].

This work used a TiHAP photocatalyst to degrade BPA and compared the photocatalytic activity of TiHAP to that of commercial P25 $\mathrm{TiO}_{2}$. The adsorption capacity and photocatalytic ability with low concentration BPA were explored. Fulvic acid (FA) and $\mathrm{Fe}^{3+}$ ions commonly exist in water and can influence the adsorption, sedimentation, and light absorption of nanoparticles [23]. This paper also investigated the effects of FA and $\mathrm{Fe}^{3+}$ on the photocatalytic degradation of BPA over TiHAP films.

\section{Experimental}

\subsection{Preparation of TiHAP powder}

TiHAP with $10 \mathrm{~mol} \%$ Ca substituted by Ti was provided by Environmental and Energy Research Center, Fujitus Laboratories Ltd., Japan. The TiHAP powder was synthesized using the coprecipitation method in the literature [19]. HAP was purchased from Shanghai Hualan Chemical Technology Co., Ltd. P25 $\mathrm{TiO}_{2}$ was purchased from Degussa Co. with a particle size of $30 \mathrm{~nm}$, specific surface area of $46.9 \mathrm{~m}^{2} / \mathrm{g}, 80 \%$ anatase and average pore diameter of $15.5 \mathrm{~nm}$.

\subsection{Characterization of TiHAP}

The morphology of TiHAP was characterized by transmission electron microscopy (TEM, Hitachi, JEM-200CX) with the stripe resolution ratio of 2.04, point resolution ratio of $0.24 \mathrm{~nm}$, and acceleration voltage of $300 \mathrm{kV}$. The crystal structure of TiHAP was identified by X-ray diffraction (XRD) with a Rigaku Dmax/2000 diffractometer (Japan) using $\mathrm{Cu} K_{\alpha}$ radiation $(\lambda=$ $0.154 \mathrm{~nm}$ ) in the scan range of $20^{\circ}-80^{\circ}$. The BET surface areas of the samples were recorded with a Micromeritics ASAP 2020 instrument. The ultraviolet-visible (UV-Vis) diffuse reflection spectra of the samples were determined by UV-Vis spectrophotometry (Shimadzu, UV-3100) with wavelengths from 200 to $800 \mathrm{~nm}$. The zeta potential of the particles suspended in deionized water (particle loading $100 \mathrm{mg} / \mathrm{L}$ ) was analyzed with a Nano ZS90 apparatus (Malvern, UK). The pH values were adjusted using $\mathrm{NaOH}$ or $\mathrm{HCl}$ solutions.

\subsection{Adsorption capacity of $\mathrm{TiHAP}$ and $\mathrm{TiO}_{2}$ powder for $\mathrm{BPA}$}

BPA solutions with concentrations of $0.2,0.4,0.6,0.8,1.0$, and $1.2 \mathrm{mg} / \mathrm{L}$ were prepared, and to each was added $100 \mathrm{mg} / \mathrm{L}$ TiHAP or $\mathrm{TiO}_{2}$, which was mixed thoroughly. The solutions were placed in a water bath $\left(25^{\circ} \mathrm{C}\right)$ and stirred $(150 \mathrm{r} / \mathrm{min})$ in darkness for $24 \mathrm{~h}$ to achieve adsorption equilibrium. Then the filtrate was obtained with $0.22 \mu \mathrm{m}$ syringe filters.

\subsection{Photocatalytic activity of TiHAP and $\mathrm{TiO}_{2}$ films for $\mathrm{BPA}$ degradation}

\subsubsection{Preparation of TiHAP and $\mathrm{TiO}_{2}$ films}

TiHAP powder $(1.9425 \mathrm{~g})$ and $10 \mathrm{~mL}$ of ultra-pure water were added onto a Petri dish (diameter of $9 \mathrm{~cm}$ ) and mixed thoroughly. The solution was dried at $98{ }^{\circ} \mathrm{C}$ for $1 \mathrm{~h}$, and a homogeneous thin film of TiHAP was formed at the bottom. This was cooled at room temperature for further use.

P25 $\mathrm{TiO}_{2}$ powder $(1.8075 \mathrm{~g})$ and $10 \mathrm{~mL}$ of ultra-pure water were added to a Petri dish (diameter of $9 \mathrm{~cm}$ ) and mixed thoroughly. The solution was dried at $80^{\circ} \mathrm{C}$ for $5 \mathrm{~h}$, and a homogeneous thin film of $\mathrm{TiO}_{2}$ was formed at the bottom. This was cooled at room temperature for further use.

\subsubsection{Photocatalytic degradation of $B P A$}

A $50 \mathrm{~mL}$ of solution (1 mg/L BPA) was dropped onto the prepared $\mathrm{TiHAP}$ or $\mathrm{TiO}_{2}$ film. After adsorption for $2 \mathrm{~h}$ in darkness, the film was put in a photoreactor with a UV lamp at the 
wavelength of $365 \mathrm{~nm}$. The lamp was $15 \mathrm{~cm}$ above the film and the light intensity was $1.2 \mathrm{~mW} / \mathrm{cm}^{2}$. For the experiments, the illumination time was set to $6 \mathrm{~h}$. A $1.0 \mathrm{~mL}$ sample was taken for LC-MS analysis every $0.5 \mathrm{~h}$. The films were very stable, and no dissolution or dispersion was observed during experiments.

The photocatalytic degradation of pollutants was fitted with a first order kinetics equation $\ln \left(C_{0} / C_{t}\right)=k t$, where $C_{t}$ represented the concentration $(\mathrm{mg} / \mathrm{L})$ at time $t, C_{0}$ was the initial concentration $(\mathrm{mg} / \mathrm{L})$, and $k$ was the reaction rate constant $\left(\mathrm{h}^{-1}\right)$.

In order to study the effects of $\mathrm{FA}$ and $\mathrm{Fe}^{3+}$ on the photocatalytic degradation of BPA, $50 \mathrm{~mL}$ of BPA solutions $(1 \mathrm{mg} / \mathrm{L})$ were prepared with different FA concentrations $(2.5,5$, and 7.5 mg/L). BPA solutions (1 mg/L) with $\mathrm{FeCl}_{3}$ (3.24, 8.11, and $16.22 \mathrm{mg} / \mathrm{L}$ ) were also prepared.

\subsubsection{Analytical methods}

BPA concentration was determined by a liquid chromatography-mass spectrometer (LC-MS, HP1100 LC-MSn Trap SL System, Agilent Technologies Co., USA) equipment with a Zorbax Eclipse XDB-C18 column $(2.1 \mathrm{~mm} \times 150 \mathrm{~mm}$, particle size $5 \mu \mathrm{m}$, pore diameter $8.0 \mathrm{~nm}$, monomeric, double-capped). Methanol/water $(75 \%, \mathrm{v} / \mathrm{v})$ was the mobile phase at a flow rate of $0.18 \mathrm{~mL} / \mathrm{min}$. The analysis time was $6.5 \mathrm{~min}$. The LC-MS was equipped with ionization by electronic spray ions (ESI) and it was operated in the secondary MS anion scanning mode. The quantitative analysis of BPA was conducted in the MRM fragmentation mode with the target ion of $m / z 227\left([\mathrm{M}-\mathrm{H}]^{-}\right)$ and the scanning range of 50-400. The maximum MS data accumulation time was $300 \mathrm{~ms}$. The capillary voltage was $3500 \mathrm{~V}$. The vaporization pressure was $2.4 \times 10^{5} \mathrm{~Pa}$. The flow rate of the drying gas $\left(\mathrm{N}_{2}, 330^{\circ} \mathrm{C}\right)$ was $8.0 \mathrm{~L} / \mathrm{min}$. The breakup voltage was $1.3 \mathrm{eV}$. The standard curve for concentration versus peak area was obtained by preparing a series of BPA (purity > 97\%, Acros Organics, Geel Belgium) solutions with methanol (Scharlau, Belgium, HPLC grade). $\mathrm{FeCl}_{3}$ and $\mathrm{FA}\left(\mathrm{C}_{14} \mathrm{H}_{12} \mathrm{O}_{8}\right)$ used were analytically pure.

\section{Results and discussion}

\subsection{Morphological and structural characteristics of the TiHAP particles}

The TEM image of the TiHAP powder is shown in Fig. 1. TiHAP exhibited an aggregated structure made of spherical and

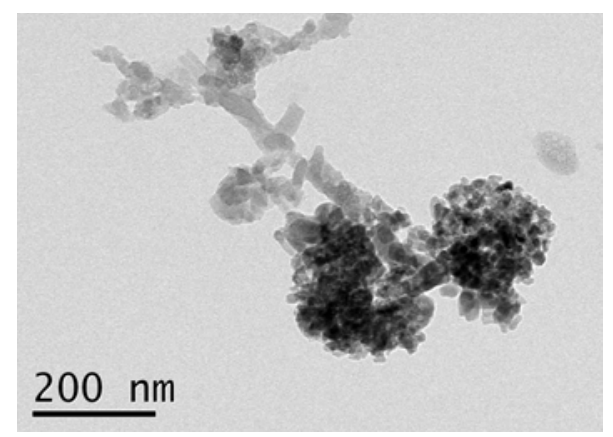

Fig. 1. TEM image of TiHAP powder.

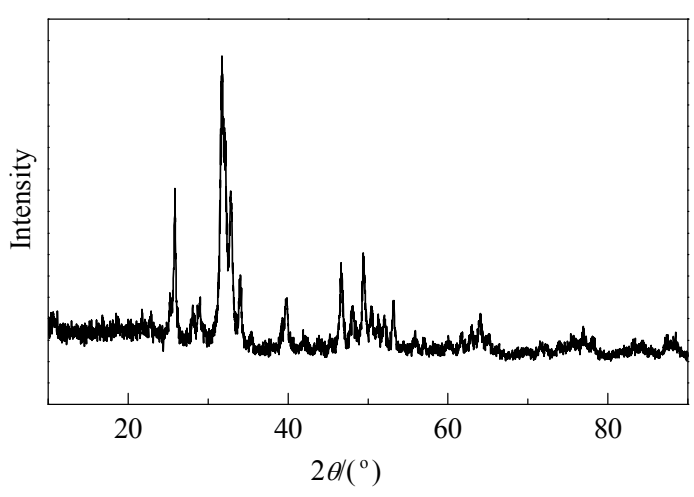

Fig. 2. XRD pattern of the TiHAP powder.

rod-like particles of irregular sizes. The XRD pattern of TiHAP is shown in Fig. 2. The characteristic diffraction peak of TiHAP was in accordance with that of HAP (JCPDS 9-432), showing the hexagonal apatite structure [21]. However, no characteristic peak of $\mathrm{TiO}_{2}$ in $\mathrm{TiHAP}$ was observed, indicating that $\mathrm{Ti}^{4+}$ was completely incorporated into the crytical lattice of HAP [22].

Figure 3 shows the UV-Vis diffuse reflectance spectra of HAP, TiHAP, and $\mathrm{P} 25 \mathrm{TiO}_{2}$. The measured band gap energy of TiHAP and $\mathrm{P} 25 \mathrm{TiO}_{2}$ were 3.45 and $3.02 \mathrm{eV}$, respectively, while the band gap energy of HAP was larger than $6.0 \mathrm{eV}$, which was consistent with the results of Tsukada et al. [21]. TiHAP showed a larger band gap and stronger absorption towards UV light than $\mathrm{TiO}_{2}$, which indicated that TiHAP would exhibit photocatalytic activity in the near UV region. The result also implied that the surface of TiHAP was modified by the substitution with $\mathrm{Ti}^{4+}$ [22].

Figure 4 illustrates the surface zeta potential versus $\mathrm{pH}$ for the TiHAP and $\mathrm{P} 25 \mathrm{TiO}_{2}$ powders. Generally, the system was stable when the absolute zeta potential was larger than $30 \mathrm{mV}$. As seen in Fig. 4, $\mathrm{TiO}_{2}$ was stable in strong acidic or alkaline solutions, while TiHAP was stable only in strong acid solution. The $\mathrm{pH}$ of the isoelectric point (IEP) for $\mathrm{TiO}_{2}$ was 6.4, which was close to the values of 5.8-7.0 reported previously [24,25]. The $\mathrm{pH}$ of the IEP for TiHAP was 2.7. There were hydroxyls on the surface of $\mathrm{TiO}_{2}$ and TiHAP. According to proton transfer theory [26], at a pH below the IEP, the proton concentration is high, and protons have the trend of migrating to the surface of

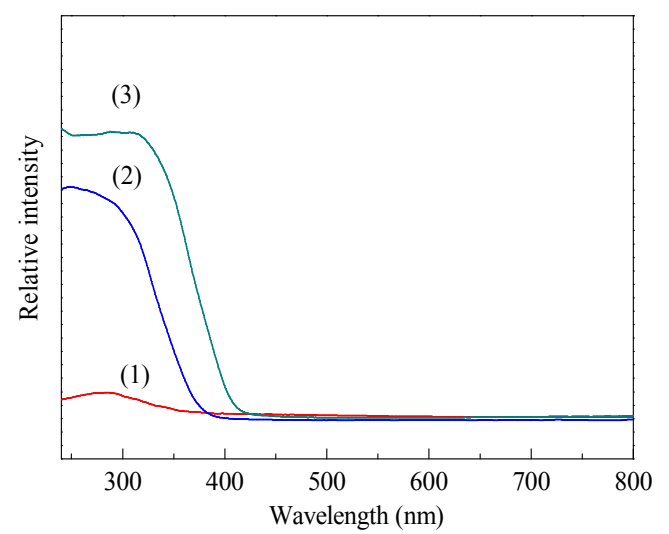

Fig. 3. UV-Vis diffuse reflectance spectra of the HAP (1), TiHAP (2), and $\mathrm{P} 25 \mathrm{TiO}_{2}(3)$ powders. 


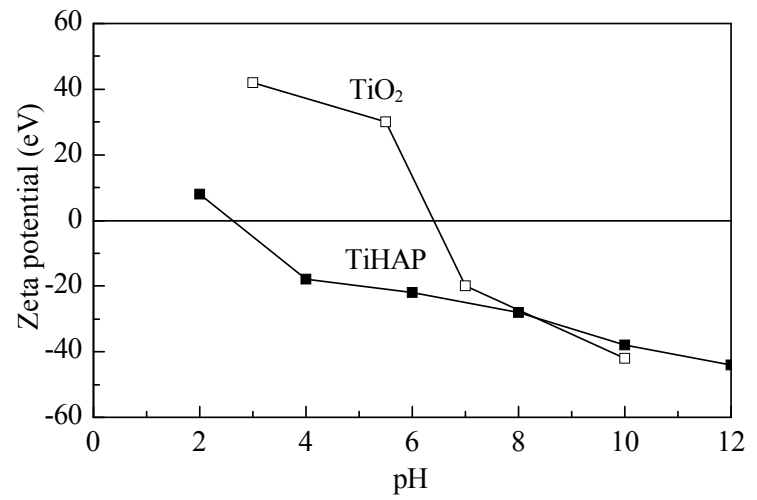

Fig. 4. Zeta potential of TiHAP and $\mathrm{P} 25 \mathrm{TiO}_{2}$ versus $\mathrm{pH}$.

particles. Thus, the surface hydroxyls have protons and became positive. At $\mathrm{pH}$ values above the IEP, surface hydroxyls lose protons and became negative. The IEP of TiHAP was lower than that of $\mathrm{TiO}_{2}$, indicating that TiHAP would more easily lose protons and adsorb more acid groups such as hydroxyls [24]. The specific surface area of TiHAP was $45.9 \mathrm{~m}^{2} / \mathrm{g}$, and the average pore diameter was $14.2 \mathrm{~nm}$ from the BET results.

\subsection{Adsorption behavior of BPA on the particles}

Langmuir, Freundlich, and Temkin adsorption isotherms were used to fit the adsorption of BPA on the TiHAP and $\mathrm{TiO}_{2}$ particles. The Langmuir equation was $1 / G=1 / G^{0}+\left(A / G^{0}\right)(1 / C)$, where $G$ is the adsorption amount, $G^{0}$ is the saturated adsorption per surface area, $C$ is the equilibrium concentration, and $A$ is a constant. $1 / G$ and $1 / C$ were used as the $Y$-axis and $X$-axis, respectively, and a linear fit was obtained, as shown in Fig. 5. The Freundlich equation was $\log G=A+(1 / n) \log C$, where $G$ is the adsorption amount, $C$ is the equilibrium concentration, $A$ and $n$ are constants, and a linear fit was obtained similarly. The Temkin equation was $G=A+B \lg C$, where $G$ is the adsorption amount, $C$ is the equilibrium concentration, and $A$ and $B$ are two constants. Table 1 lists the fitting results of three adsorption equations of Langmuir, Freundlich, and Temkin. The fitting correlation coefficient of the Langmuir equation fit was larger than that of the Freundlich and Temkin equation fits, indicating that the adsorption of BPA on the TiHAP and $\mathrm{TiO}_{2}$ particles were better fitted by the Langmuir isotherm. The adsorption heat does not change during Langmuir adsorption, and the energy of each adsorption point is the same, which represents homogeneous surface adsorption.

The intercept of the regression line was the reciprocal of the saturation adsorption capacity $\left(G_{0}\right)$. It gave the saturated adsorption amounts of BPA on TiHAP and $\mathrm{TiO}_{2}$ as 8.55 and 0.45 $\mathrm{mg} / \mathrm{g}$, respectively. The adsorption capacity of TiHAP for BPA was higher than that of $\mathrm{TiO}_{2}$.

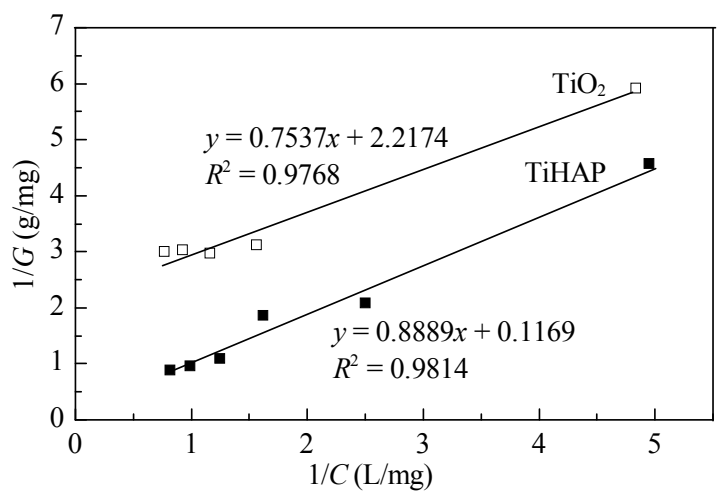

Fig. 5. Langmuir adsorption isotherm of BPA on the TiHAP and P25 $\mathrm{TiO}_{2}$ particles.

As shown in Fig. 4, the zeta potentials of $\mathrm{TiHAP}$ and $\mathrm{TiO}_{2}$ did not show significant difference when the $\mathrm{pH}$ was about 7 , suggesting that the surface charge was not the reason for the different adsorption capacities of the particles. In addition, the specific surface area and average pore diameter of TiHAP and $\mathrm{TiO}_{2}$ were comparable, so these would not lead to the different adsorption capacities either. It is known that TiHAP is produced from a substitution of HAP by Ti, which resulted in multiple Ti-OH groups on the TiHAP surface [27]. Large amounts of phosphates and hydroxyls in the crystal lattice of TiHAP can adsorb the hydroxyls of BPA by hydrogen bonding. Although Ti-OH groups existed on the $\mathrm{P}^{2} 5 \mathrm{TiO}_{2}$ surface as well, the experimental results showed that the adsorption capacity of TiHAP for BPA was larger than that of $\mathrm{TiO}_{2}$.

\subsection{Photocatalytic activity of the TiHAP and $\mathrm{TiO}_{2}$ films for $\mathrm{BPA}$ degradation}

\subsubsection{Photocatalytic activity}

The blank experiment exhibited that no direct photolysis of BPA was observed with $365 \mathrm{~nm}$ UV light illumination. In addition, the HAP sample showed no photocatalytic activity. The UV-Vis diffuse spectra (Fig. 3) indicated that HAP could only be excited by UV light with wavelengths shorter than $300 \mathrm{~nm}$. Therefore, HAP would not show catalytic activity under these experimental conditions. Figure 6 shows the photocatalytic degradation curves of BPA with the TiHAP and $\mathrm{TiO}_{2}$ films. The photodegradation rate of BPA was $0.115 \mathrm{~h}^{-1}$ over the TiHAP film, which was 2.4 times larger than that of the $\mathrm{TiO}_{2}$ film $\left(0.048 \mathrm{~h}^{-1}\right)$. The TiHAP film showed an enhanced photocatalytic activity over that of $\mathrm{P}_{2} 5 \mathrm{TiO}_{2}$ for the degradation of BPA.

\subsubsection{Effect of FA on photocatalytic degradation of BPA}

Figure 7 exhibits the photocatalytic degradation rate of BPA coexisting with different FA concentrations over the TiHAP and

\section{Table 1}

Linear fit results for the three adsorption equations.

\begin{tabular}{lccc}
\hline Sample & Langmuir equation & Freundlich equation & Temkin equation \\
& $1 / G=1 / G^{0}+\left(\mathrm{A} / G^{0}\right)(1 / C)$ & $\lg G=A+(1 / n) \lg C$ & $G=A+B \lg C$ \\
\hline TiHAP & $1 / G=0.1169+0.8889(1 / C), R^{2}=0.9814$ & $\lg G=-0.0036+0.9213 \lg C, R^{2}=0.9676$ & $G=0.9794+1.1977 \lg C, R^{2}=0.9233$ \\
$\mathrm{TiO}_{2}$ & $1 / G=2.2174+0.7537(1 / C), R^{2}=0.9768$ & $\lg G=-0.4675+0.3325 \lg C, R^{2}=0.7022$ & $G=0.3377+0.1862 \lg C, R^{2}=0.7196$ \\
\hline
\end{tabular}




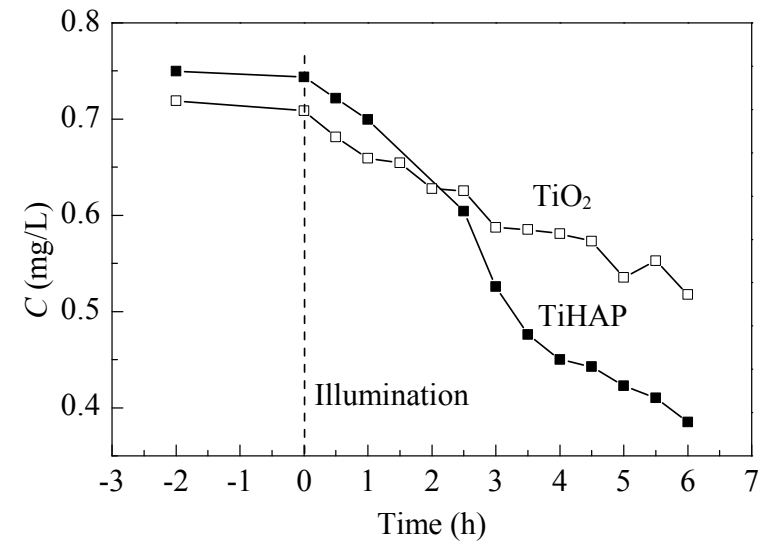

Fig. 6. Photocatalytic degradation curves of bisphenol A (BPA) over the TiHAP and $\mathrm{TiO}_{2}$ films.

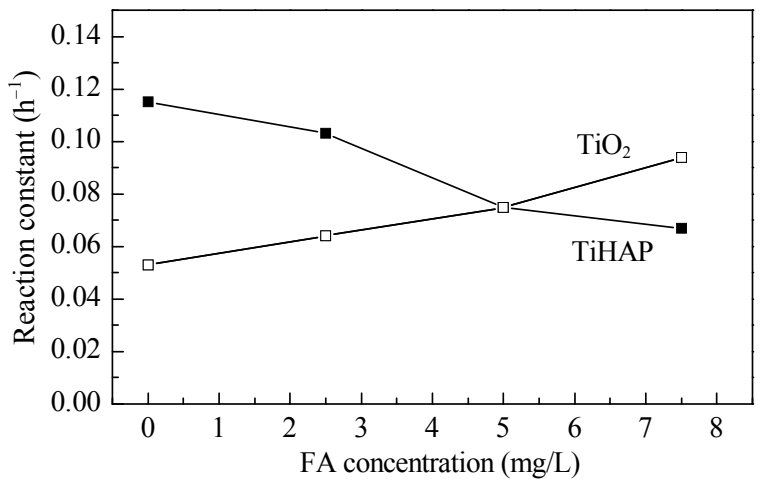

Fig. 7. Photocatalytic degradation rate of BPA versus fulvic acid (FA) concentration over the TiHAP and $\mathrm{TiO}_{2}$ films.

$\mathrm{TiO}_{2}$ films. With the increase of FA concentration, the degradation rate of BPA over the TiHAP films was successively reduced, which was in contrast to the trend of degradation rate of BPA over $\mathrm{TiO}_{2}$ films. The reason was that the lowest unoccupied molecular orbital of FA was higher than the conduction band of $\mathrm{TiO}_{2}$. After excitation, the photoinduced electrons of FA can transfer to the conduction band of $\mathrm{TiO}_{2}$ and react with adsorbed $\mathrm{O}_{2}$, followed by the formation of $\bullet_{2}{ }^{-}$[28], which thereby improved the oxidation removal efficiency of BPA. However, TiHAP has a large band gap and a high conduction band [21]. The photoinduced electrons of FA cannot transfer to the conduction band of TiHAP. Conversely, the photoinduced electrons of TiHAP is transferred to the ground state of FA, that is, FA quenched the excited electrons in TiHAP, and the photocatalytic removal efficiency of BPA was reduced. Another possible reason for the promotion effect of FA in the photocatalytic degradation of BPA over $\mathrm{TiO}_{2}$ film may be that FA can serve as the trapping agent of photoinduced holes. The increased separation efficiency of the photoinduced electron-hole pair resulted in enhanced photocatalytic efficiency with increased FA concentration.

\subsubsection{Effect of $\mathrm{Fe}^{3+}$ on the photocatalytic degradation of BPA}

Figure 8 shows the photocatalytic degradation rate of BPA over the TiHAP and $\mathrm{TiO}_{2}$ films with different $\mathrm{Fe}^{3+}$ concentra-

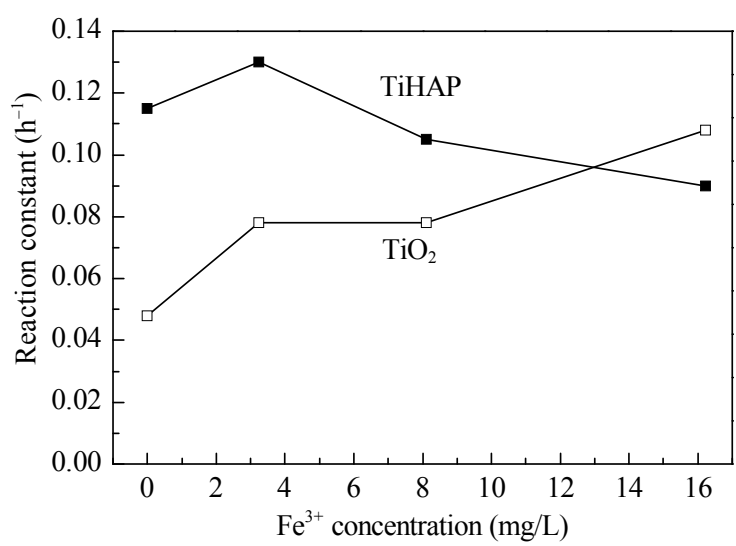

Fig. 8. Photocatalytic degradation rate of $\mathrm{BPA}$ versus $\mathrm{Fe}^{3+}$ concentration over the TiHAP and $\mathrm{TiO}_{2}$ films.

tions. With the increase of $\mathrm{Fe}^{3+}$ concentration, the photocatalytic activity of $\mathrm{TiO}_{2}$ gradually increased. $\mathrm{Fe}^{3+}$ can capture photoinduced electrons [29] and increase the separation efficiency of the electron-hole pair, thereby facilitating the action of the photoinduced hole. Thus, more reactive oxygen species, such as hydroxyl free radicals, were produced, which enhanced the oxidative degradation of BPA. TiHAP showed a different trend of photocatalytic activity change. With the increase of $\mathrm{Fe}^{3+}$ concentration, the degradation rate of BPA first increased and then decreased. This may be attributed to the relatively low density of photoinduced electron-hole pairs on the TiHAP surface. Therefore, $\mathrm{Fe}^{3+}$ at low concentrations facilitated the separation of electron-hole pairs. Conversely, $\mathrm{Fe}^{3+}$ at high concentrations serves as recombination centers of electron-hole pairs, resulting in less reactive oxidizing species being generated. Another possible reason was that TiHAP had weak UV absorption at the wavelength of $365 \mathrm{~nm}$. With higher $\mathrm{Fe}^{3+}$ concentrations, the deeper color of the solution would lead to decreased light absorption and decreased catalytic activity.

\section{Conclusions}

The adsorption of BPA on the TiHAP and $\mathrm{TiO}_{2}$ powders was well described by the Langmuir adsorption equation. TiHAP exhibited a large adsorption capacity for BPA, which was 19 times as large as that of $\mathrm{TiO}_{2}$ under the same conditions. This was due to hydrogen bonds formed between the hydroxyl groups of BPA and the hydroxyl groups on the TiHAP surface. The first order photocatalytic degradation rate constant of BPA over the TiHAP film was 2.4 times as large as that of $\mathrm{TiO}_{2}$. An increase of radiation intensity would improve the catalytic activity. The photocatalytic mechanism of TiHAP needs to be further discussed. The results are useful for the application of TiHAP in the photocatalytic degradation of environmental endocrine disrupting chemicals.

\section{References}

[1] Nagel S C, vom Saal F S, Thayer K A, Dhar M G, Boechler M, Welshons W V. Environ Health Persp, 1997, 105: 70 


\title{
Graphical Abstract
}

Chin. J. Catal., 2014, 35: 90-98 doi: 10.1016/S1872-2067(12)60709-8

\section{Photocatalytic degradation of bisphenol A using Ti-substituted hydroxyapatite}

Qian Li, Xiang Feng, Xiao Zhang, Han Song, Jianwei Zhang, Jing Shang*, Weiling Sun, Tong Zhu, Masato Wakamura, Mineharu Tsukada, Yingliang Lu Peking University, China;

Fujitsu Laboratories Limited, Japan;

Fujitsu Research and Development Center, China

TiHAP film showed an enhanced photocatalytic activity than $\mathrm{P} 25 \mathrm{TiO}_{2}$ film for degradation of bisphenol (BPA), an important kind of environmental endocrine disrupting chemicals.

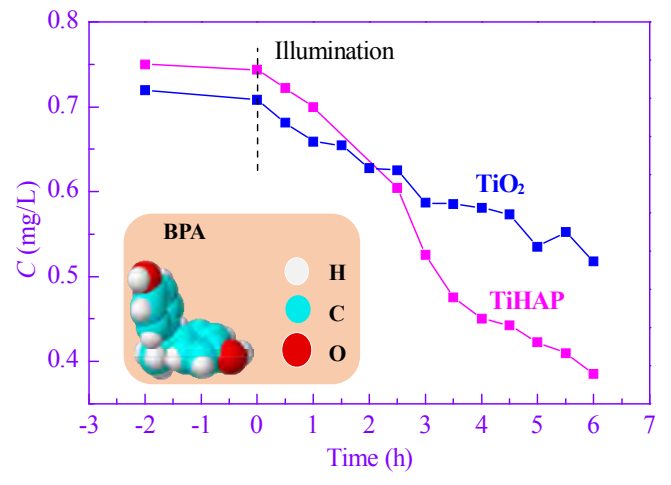

[2] Garoma T, Matsumoto S A, Wu Y, Klinger R. Ozone-Sci Eng, 2010, 32: 338

[3] Staples C A, Dome P B, Klecka G M, Oblock S T, Harris L R. Chemosphere, 1998, 36: 2149

[4] Fromme H, Küchler T, Otto T, Pilz K, Müller J, Wenzel A. Water Res, 2002, 36: 1429

[5] Zhang H F, Hu J Y, Chang H, Wang X L, Gao J F, Dong M Q. Environ Chem (张海峰, 胡建英, 常红,王秀丽, 高建峰, 董民强. 环境化学), 2004, 23: 584

[6] Du B, Zhang P Y, Zhang Z L, Yu G. Chin J Environ Sci (杜兵, 张彭义, 张祖麟, 余刚. 环境科学), 2004, 25: 114

[7] Kang J H, Kondo F, Katayama Y. Toxicology, 2006, 226: 79

[8] Katsumata H, Kawabe S, Kaneco S, Suzuki T, Ohta K. J Photochem Photobiol A, 2004, 162: 297

[9] Rosenfeldt E J, Linden K G. Environ Sci Technol, 2004, 38: 5476

[10] Chen P J, Linden K G, Hinton D E, Kashiwada S, Rosenfeldt E J, Kullman S W. Chemosphere, 2006, 65: 1094

[11] Korshin G V, Kim J, Gan L. Water Res, 2006, 40: 1070

[12] Yang J, Dai J, Li J T. Appl Surf Sci, 2011, 257: 8965

[13] Kuruto-Niwa R, Terao Y, Nozawa R. Environ Toxicol Pharm, 2002, 12: 27

[14] Ohko Y, Ando I, Niwa C, Tatsuma T, Yamamura T, Nakashima T, Kubota Y, Fujishima A. Environ Sci Technol, 2001, 35: 2365

[15] Torres R A, Nieto J I, Combet E, Pétrier C, Pulgarin C. Appl Catal B, 2008, 80: 168
[16] He Y, Duan H J, Wang G H, Guo C S, Wang Y Q. Acta Sci Circumstantiae (贺艳, 段海静, 王广华, 郭昌胜, 王玉秋. 环境科 学学报), 2011, 31: 2179

[17] Kuo C Y, Wu C H, Lin H Y. Desalination, 2010, 256: 37

[18] Xie Y B, Li X Z.J Hazard Mater, 2006, 138: 526

[19] Kandori K, Toshima S, Wakamura M, Fukusumi M, Morisada Y. J Phys Chem B, 2010, 114: 2399

[20] Wakamura M, Hashimoto K, Watanabe T. Langmuir, 2003, 19: 3428

[21] Tsukada M, Wakamura M, Yoshida N, Watanabe T. J Mol Catal A, 2011, 338: 18

[22] Kandori K, Kuroda T, Wakamura M. Colloids Surf B, 2011, 87: 472

[23] Li S, Sun W L. J Hazard Mater, 2011, 197: 70

[24] Miyauchi M, Ikezawa A, Tobimatsu H, Irie H, Hashimoto K. Phys Chem Chem Phys, 2004, 6: 865

[25] Liao D L, Wu G S, Liao B Q. Colloids Surf A, 2009, 348: 270

[26] Chadwick M D, Goodwin J W, Lawson E J, Mills P D A, Vincent B. Colloids Surf A, 2002, 203: 229

[27] Wakamura M, Kandori K, Ishikawa T. Colloids Surf A, 2000, 164: 297

[28] Wang H J, Wu X J, Wang Y L, Jiao Z B, Yan S W, Huang L H. Chin J Catal (王后锦, 吴晓婧, 王亚玲, 焦自斌, 颜声威, 黄浪欢. 催化学 报), 2011, 32: 637

[29] Shang J, Xue L, Li J, Zhao F W. Chin J Catal (尚静, 薛莲, 李佳, 赵风 伟. 催化学报), 2008, 29: 1037

\section{载钛羟基磷灰石光催化降解内分泌干扰物双酚 $\mathbf{A}$}

\author{
李 前 ${ }^{\mathrm{a}}$, 冯 想, 张 晓 ${ }^{\mathrm{a}}$, 宋 寒 ${ }^{\mathrm{a}}$, 张建伟, 尚 静 ${ }^{\mathrm{a},}{ }^{*}$, 孙卫玲 ${ }^{\mathrm{a}}$, 朱 䑣 ${ }^{\mathrm{a}}$ \\ 若村正人 ${ }^{\mathrm{b}}$, 塚田峰春 ${ }^{\mathrm{b}}$, 陆应亮 ${ }^{\mathrm{c}}$ \\ a 北京大学环境科学与工程学院, 北京 100871 \\ 富士通研究所环境能源研究中心, 日本神奈川县厚木市 \\ c富士通研究开发中心有限公司, 北京 100025
}

\begin{abstract}
摘要: 对载钛羟基磷灰石(TiHAP)进行了透射电镜、X射线衍射、紫外-可见光谱和Zeta电位表征, 并应用液相色谱-质谱技术对比 了 TiHAP和P $25 \mathrm{TiO}_{2}$ 对环境内分泌干扰物双酚 $\mathrm{A}(\mathrm{BPA})$ 的吸附和光催化降解性能, 探讨了富里酸和Fe ${ }^{3+}$ 对 $\mathrm{TiHAP}$ 薄膜光催化性能的 影响. 结果表明, TiHAP和 $\mathrm{TiO}_{2}$ 粉体对BPA的吸附符合Langmuir吸附等温方程, 且前者吸附性能更大. TiHAP薄膜光催化降解BPA 的性能优于 $\mathrm{TiO}_{2}$ 薄膜; 富里酸和 $\mathrm{Fe}^{3+}$ 对 $\mathrm{TiHAP}$ 和 $\mathrm{TiO}_{2}$ 薄膜光催化性能的影响趋势不同, 从能带结构、电子转移和吸光性等角度分 析了性能不同的原因. 本结果可以为应用TiHAP降解环境内分泌干扰物提供依据.
\end{abstract}


关键词: 载钛羟基磷灰石; 光催化; 双酚 $\mathrm{A}$; 吸附; 二氧化钛

收稿日期: 2013-07-22. 接受日期: 2013-09-11. 出版日期: 2014-01-20.

*通讯联系人. 电话: (010)62759716; 电子信箱: shangjing@pku.edu.cn

基金来源：日本富士通研究所环境能源研究中心基金(k120400); 北京市自然科学基金(8132035); 国家自然科学基金(21277004, 21190051, 41121004).

本文的英文电子版由Elsevier出版社在ScienceDirect上出版(http://www.sciencedirect.com/science/journal/18722067).

\section{1. 前言}

双酚A (BPA)广泛应用于环氧树脂、聚碳酸酯树脂 和聚苯乙烯树脂的制造中 ${ }^{[1]}$. 这些终产品(如塑料制品、 食品容器、医疗用品等)如果处理不当可能会直接排入 河流及海洋中, 或随垃圾处理产生的废液排出, 导致 $\mathrm{BPA}$ 释放到环境介质特别是水生环境中 ${ }^{[2]}$. 近年来, 在 国内外的原水及饮用水中BPA频频被检出 ${ }^{[3]}$. 例如, 1997 年在德国地表水中检测到 BPA 浓度为 0.5-410 $\mathrm{ng} / \mathrm{L}^{[4]} ; 2002-2003$ 年在杭州饮用水源中检测到BPA浓 度为 $0.33-25.09 \mathrm{ng} / \mathrm{L}^{[5]}$. 2002年对北京市某典型污水处 理厂的调查中, 共检出 30 种内分泌干扰物, 其中BPA含 量最高, 达 $0.825 \mathrm{mg} / \mathrm{L}^{[6]}$. 我国《生活饮用水卫生标准》 (GB 5749-2006)中规定BPA的限值为 $0.01 \mathrm{mg} / \mathrm{L}$. BPA是 一种环境内分泌干扰物, 有模拟雌激素的作用, 影响机 体的生理功能, 即使很低的剂量也能使动物产生雌性早 熟、精子数下降和前列腺增长等, 还有一定的胚胎毒性 和致畸性. 通过直接接触或生物链的积累效应. BPA还 可能进入人体, 导致人体内分泌失衡, 扰乱人体代谢过 程, 对贞儿发育、免疫力有影响, 还可能导致男性不育甚 至致癌 ${ }^{[7]}$. 因此, 去除液相中的BPA尤为重要. 传统的 BPA处理方法主要有生物法、物理法以及化学法. 其中 化学法是使用化学试剂或催化剂, 通过发生化学反应使 BPA氧化降解, 主要包括Fenton氧化处理法 ${ }^{[8]}$ 、紫外光氧 化法 ${ }^{[9]} 、 \mathrm{H}_{2} \mathrm{O}_{2}$ 氧化法 ${ }^{[10]}$ 、氯氧化法 ${ }^{[1]}$ 及光催化氧化法 ${ }^{[12]}$ 等. 单一的Fenton氧化、紫外光氧化或 $\mathrm{H}_{2} \mathrm{O}_{2}$ 氧化法对 BPA的去除效果较差, 不能使其完全去除, 常需几种方 法联用. 氯氧化处理方法不仅要加入大量化学试剂造成 成本较高, 还会因为BPA氧化降解不彻底, 氯与BPA反 应的副产物有更强的内分泌干扰作用 ${ }^{[13]}$, 反而加大其环 境激素效应和毒性.

光催化作为一种高级氧化技术可用来处理有机和 无机污染物, 与传统处理技术相比, 具有催化效率高、氧 化彻底和能耗低等优势. 近年来, 关于 $\mathrm{TiO}_{2}$ 在紫外光照 下光催化降解BPA已有很多报道. 已经证明, 采用 $\mathrm{TiO}_{2}$ 光催化技术可将 $\mathrm{BPA}$ 彻底氧化成 $\mathrm{CO}_{2}$ 和 $\mathrm{H}_{2} \mathrm{O}$, 无二次污
染产生 ${ }^{[14]}$. 并且, 反应一定时间时体系中雌激素活性可 减少到原溶液的 $10 \%$ 以下 ${ }^{[14]} ; \mathrm{TiO}_{2}, \mathrm{H}_{2} \mathrm{O}_{2}$ 和超声具有协 同作用 ${ }^{[15]} ; 3 \mathrm{D}$ 介孔 $\mathrm{TiO}_{2}$ 光催化剂的效率高于市售 $\mathrm{P} 25$ $\mathrm{TiO}_{2}$ 粉体 ${ }^{[16]}$. 对于在可见光下的研究, Kuo 等 ${ }^{[17]}$ 探讨了 不同 $\mathrm{pH}$ 及聚乙二醇添加剂对 $\mathrm{TiO}_{2}$ 光催化降解BPA的影 响. $\mathrm{TiO}_{2}$ 光催化降解BPA的过程常需要引入添加剂, 如 $\mathrm{H}_{2} \mathrm{O}_{2}{ }^{[18]}$, 为进一步提高催化效率和降低成本, 需要开发 新型高效的光催化剂.

载钛羟基磷灰石(TiHAP)是一种新型光催化剂, 是 $\mathrm{Ti}^{4+}$ 置换羟基磷灰石(HAP)中的一部分 $\mathrm{Ca}^{2+}$ 而形成的一 种晶体. HAP是一种广泛采用的医用材料, 可用于牙齿 或骨组织修复; 它的分子式为 $\mathrm{Ca}_{10}\left(\mathrm{PO}_{4}\right)_{6}(\mathrm{OH})_{2}$, 其中的 $\mathrm{Ca}^{2+}$ 可被多种阳离子取代. Kandori等 ${ }^{[19]}$ 用金属离子 $\mathrm{Al}^{3+}, \mathrm{La}^{3+}$ 及 $\mathrm{Fe}^{3+}$ 替换 HAP 中的 $\mathrm{Ca}^{2+}$, 考察了改性后的 HAP对蛋白质的吸附性能及影响因素. Wakamura等 ${ }^{[20]}$ 将 $\mathrm{Ti}^{4+}$ 置换 $\mathrm{HAP}$ 中的部分 $\mathrm{Ca}^{2+}$, 所制TiHAP在近紫外光下 表现出光催化活性. Tsukada等 ${ }^{[21]}$ 分析和计算了 $\mathrm{Ti}^{4+}$ 掺杂 后所引起的能带结构和吸光特性的变化. TiHAP作为一 种新型光催化剂的同时, 还显示出比 $\mathrm{TiO}_{2}$ 更优异的吸附 性能 ${ }^{[22]}$.

本文首次应用 TiHAP光催化降解BPA, 并与常用的 商业P25 $\mathrm{TiO}_{2}$ 作对比, 研究其对低浓度BPA的吸附和光 催化降解特性. 富里酸 $(\mathrm{FA})$ 和 $\mathrm{Fe}^{3+}$ 是水体中普遍存在的 物质, 对纳米颗粒物的吸附、沉降及吸光性有影响 ${ }^{[23]}$, 因 此还考察了 $\mathrm{FA}$ 和 $\mathrm{Fe}^{3+}$ 对TiHAP薄膜光催化降解BPA性能 的影响.

\section{2. 实验部分}

\subsection{TiHAP粉体的制备}

TiHAP粉体由日本富士通研究所环境能源研究中 心提供, 采用共沉淀法制备 ${ }^{[19]}$, 特征是HAP中 $10 \mathrm{~mol} \%$ 的

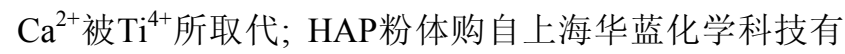
限公司; $\mathrm{P} 25 \mathrm{TiO}_{2}$ 粉体购自 Degussa公司, $\mathrm{P} 25 \mathrm{TiO}_{2}$ 的粒 径为 $30 \mathrm{~nm}$, 比表面积 $46.9 \mathrm{~m}^{2} / \mathrm{g}$, 平均孔径 $15.5 \mathrm{~nm}$, 是锐 钛矿与金红石的混晶, 其中锐铁矿含量为 $80 \%$.

\subsection{TiHAP粉体的表征}


采用日本日立公司JEM-200CX型透射电子显微镜 (TEM) 表征TiHAP粉体的形貌, 条纹分辨率 2.04 , 点分辨 率 $0.24 \mathrm{~nm}$, 加速电压 $300 \mathrm{kV}$; 采用日本 Rigaku公司 $\operatorname{Dmax} / 2000$ 型X射线衍射 $(\mathrm{XRD})$ 仪测定 TiHAP的晶型结 构, 扫描速度为 $4 \% \mathrm{~min}, \mathrm{Cu} K_{\alpha}$ 靶, $\lambda=0.154 \mathrm{~nm}$, 扫描范围 为 $2 \theta=20^{\circ}-80^{\circ}$; 采用 Micromeritics 公司 ASAP 2020 型 BET比表面积测定仪测定颗粒物的比表面积; 采用岛津 公司UV-3100型紫外可见光度计测定样品的紫外可见漫 反射光谱(UV-Vis), 波长范围200-800 nm. 采用 Nano ZS90 (Malvern, 英国) 分析颗粒物的zeta电位, 用 $\mathrm{NaOH}$ 或 $\mathrm{HCl}$ 水溶液调节体系的 $\mathrm{pH}$ 值, $\mathrm{TiHAP}$ 或 $\mathrm{TiO}_{2}$ 溶液的浓度 为 $100 \mathrm{mg} / \mathrm{L}$.

\subsection{TiHAP粉体和 $\mathrm{TiO}_{2}$ 粉体对BPA的吸附性能}

制备 $0.2,0.4,0.6,0.8,1.0$ 和 $1.2 \mathrm{mg} / \mathrm{L}$ 的 BPA系列溶 液, 分别加入 $100 \mathrm{mg} / \mathrm{L}$ 的 $\mathrm{TiHAP}$ 粉体和 $\mathrm{TiO}_{2}$ 粉体并摇晃 均匀. 置于 $25^{\circ} \mathrm{C}$ 的恒温水浴锅中, 以 $150 \mathrm{r} / \mathrm{min}$ 速度摚拌, 在黑暗中吸附 $24 \mathrm{~h}$ 后, 利用 $0.22 \mu \mathrm{m}$ 的一次性过滤头进行 过滤取样.

\subsection{TiHAP和 $\mathrm{TiO}_{2}$ 薄膜对 BPA的光催化降解}

\subsubsection{TiHAP和 $\mathrm{TiO}_{2}$ 薄膜的制备}

用直径为 $9 \mathrm{~cm}$ 的培养血称取约 $1.9425 \mathrm{~g}$ 的 TiHAP粉 末, 用约 $10 \mathrm{~mL}$ 超纯水溶解, 摇晃均匀后于 $98{ }^{\circ} \mathrm{C}$ 干燥 $1 \mathrm{~h}$ 后取出, 在培养血底部附着有一层均匀的 TiHAP薄膜, 自然冷却后待用.

用直径为 $9 \mathrm{~cm}$ 的培养血称取约 $1.8075 \mathrm{~g}$ 的 $\mathrm{P} 25 \mathrm{TiO}_{2}$ 粉末, 用约 $10 \mathrm{~mL}$ 超纯水溶解, 摇晃均匀后于 $80{ }^{\circ} \mathrm{C}$ 干燥 5 $\mathrm{h}$ 后取出, 在培养血底部附着有一层均匀的 $\mathrm{TiO}_{2}$ 薄膜, 自 然冷却后待用.

\subsection{2. 光催化降解实验}

在已制备好待用的 $\mathrm{TiHAP}$ 和 $\mathrm{TiO}_{2}$ 薄膜上滴加 $50 \mathrm{~mL}$ 的BPA溶液 $(1 \mathrm{mg} / \mathrm{L})$. 将两个培养血暗态下吸附 $2 \mathrm{~h}$ 后, 放入光反应器中. 光源为主波长为 $365 \mathrm{~nm}$ 的紫外灯, 光 源距薄膜 $15 \mathrm{~cm}$, 薄膜处光强为 $1.2 \mathrm{~mW} / \mathrm{cm}^{2}$, 每光照 $0.5 \mathrm{~h}$ 取 $1.0 \mathrm{~mL}$ 样进行液相色谱-质谱(LC-MS) 分析, 光照时间 为 $6 \mathrm{~h}$. 两种薄膜在反应溶液中的稳定性很好, 在滴加溶 液和光照的过程中没有发生溶解和分散.

对于浓度较低的反应液, 光催化降解有机物的过程 符合一级动力学方程 $\ln \left(C_{0} / C_{t}\right)=k t$, 式中, $C_{t}$ 和 $C_{0}$ 分布代 表初始和反应 $t$ 时刻的物质浓度 $(\mathrm{mg} / \mathrm{L}), k$ 代表一级动力 学方程的速率常数 $\left(\mathrm{h}^{-1}\right)$, 用以表征样品的催化性能.

分别配制FA浓度为 $2.5,5$ 和 $7.5 \mathrm{mg} / \mathrm{L}$ 的 $50 \mathrm{~mL}$ BPA 溶液 $(1 \mathrm{mg} / \mathrm{L})$; 配制 $\mathrm{FeCl}_{3}$ 浓度为 $3.24,8.11$ 和 $16.22 \mathrm{mg} / \mathrm{L}$
的 $50 \mathrm{~mL}$ BPA溶液 $\left(1 \mathrm{mg} / \mathrm{L}\right.$ ) 用以考察 $\mathrm{FA}$ 和 $\mathrm{Fe}^{3+}$ 的影响.

\subsection{3. 样品浓度测定}

使用液相色谱质谱联用仪(LC-MS, HP1100 LC-MS ${ }^{\mathrm{n}}$ Trap SL System, 美国安捷伦公司)测定样品浓度并进行 数据分析. 色谱条件: 采用Agilent公司Zorbax Eclipse XDB-C18色谱柱 $(2.1 \mathrm{~mm} \times 150 \mathrm{~mm}$, 粒径 $5 \mu \mathrm{m}$, 孔径 8.0 $\mathrm{nm}$, 单聚体, 双封端), 柱温没有限定, 进样量 $5 \mu \mathrm{L}$. 以甲 醇和水作为流动相, 其中甲醇为 $75 \%(\mathrm{v} / \mathrm{v})$, 流速 0.18 $\mathrm{mL} / \mathrm{min}$, 停止时间 $6.5 \mathrm{~min}$. 质谱条件: ESI的电喷雾源, 二级质谱负离子扫描模式, 离子阱SL系统. 对BPA的定 量分析, 采用MRM的 fragmentation模式, 目标离子 $m / z$ 227 ([M-H] $\left.]^{-}\right)$, 扫描范围 $m / z=50-400$, 最长累积时间 300 $\mathrm{ms}$, 毛细管电压 $3500 \mathrm{~V}$, 气化压力 $2.4 \times 10^{5} \mathrm{~Pa}$, 干燥气 $\left(\mathrm{N}_{2}\right)$ 流速 $8.0 \mathrm{~L} / \mathrm{min}$, 干燥气温度 $330^{\circ} \mathrm{C}$, 破碎电压 $1.3 \mathrm{eV}$. 用 色谱纯的甲醇(Scharlau, 比利时)配制一系列不同浓度的 BPA (纯度 $>97 \%$, Acros Organics, Geel Belgium), 绘制浓 度-峰面积标准工作曲线. $\mathrm{FeCl}_{3}$ 、富里酸 $\left(\mathrm{C}_{14} \mathrm{H}_{12} \mathrm{O}_{8}\right)$ 均为 分析纯.

\section{3. 结果与讨论}

\subsection{TiHAP粉体的形貌和结构特性}

图1为TiHAP粉体的TEM照片. 可以看出, TiHAP颗 粒较易团聚, 粒子呈球状和棒状, 尺寸不规则. 图 2 为 TiHAP 样品的 XRD 谱, 可见其特征衍射峰与 HAP (JCPDS 9-432)的一致, 为六边的磷灰石结构 ${ }^{[21]}$, 且未出 现 $\mathrm{TiO}_{2}$ 的特征峰, 说明 $\mathrm{Ti}^{4+}$ 离子完全进入到 HAP的晶格 中 ${ }^{[22]}$.

图3为HAP, TiHAP和P25 $\mathrm{TiO}_{2}$ 三种颗粒物的UV-Vis 漫反射谱. 可以看出, TiHAP和P $25 \mathrm{TiO}_{2}$ 对应的带隙分 别为 3.45 和 $3.02 \mathrm{eV}$ 左右, 而 $\mathrm{HAP}$ 的带隙大于 $6.0 \mathrm{eV}$, 与 Tsukada等 ${ }^{[21]}$ 的结果一致. TiHAP显示出了比 $\mathrm{TiO}_{2}$ 更大 的带隙能, 在紫外光区域有较强的吸收, 进一步说明 $\mathrm{Ti}^{4+}$ 离子进入了HAP的晶格中.

图4为 TiHAP和P25 $\mathrm{TiO}_{2}$ 的Zeta电位随 $\mathrm{pH}$ 的变化. 通常Zeta电位的绝对值在 $30 \mathrm{mV}$ 以上, 体系是稳定的. 由 图4可知, $\mathrm{TiO}_{2}$ 在较强酸性和碱性下比较稳定, 而 TiHAP 只有在强碱性下才稳定. $\mathrm{TiO}_{2}$ 的等电位点在 $\mathrm{pH}$ 6.4左右, 与文献报道的 5.8-7.0接近 ${ }^{[24,25]}$; TiHAP的等电位点在 $\mathrm{pH}$ 2.7 左右. $\mathrm{TiO}_{2}$ 和 $\mathrm{TiHAP}$ 表面存在羟基, 由质子转移理 论 ${ }^{[26]}$ 可知, 在等电点以下的低 $\mathrm{pH}$ 条件下, 质子浓度高, 有向粒子表面迁移的趋势, 使表面的羟基得到质子带正 电; 在等电位以上的高 $\mathrm{pH}$ 条件下, 羟基失去质子而带负 
电. TiHAP等电位点比 $\mathrm{TiO}_{2}$ 更低表明其更易失去质子, 吸附有更多的羟基等酸性位点 ${ }^{[24]}$. BET测试结果表明, TiHAP的比表面积为 $45.9 \mathrm{~m}^{2} / \mathrm{g}$, 平均孔径为 $14.2 \mathrm{~nm}$.

\subsection{TiHAP和 $\mathrm{TiO}_{2}$ 粉体对BPA的吸附}

本文采用Langmuir, Freundlich和 Temkin吸附等温 式拟合 $\mathrm{TiHAP}$ 和 $\mathrm{TiO}_{2}$ 对 $\mathrm{BPA}$ 的吸附. Langmuir方程为 $1 / G=1 / G^{0}+\left(A / G^{0}\right)(1 / C)$, 其中 $G$ 为吸附量, $G^{0}$ 为单位表 面上达到饱和时间的最大吸附量, $C$ 为平衡浓度, $A$ 为常 数; 以 $1 / G$ 对 $1 / C$ 作图可得到一条直线, 如图 5 所示. Freundlich方程为 $\lg G=A+(1 / n) \lg C$, 其中 $G$ 为吸附量, $C$ 为平衡浓度, $A, n$ 为常数; 以 $\lg G$ 对 $\lg C$ 作图可得到一条 直线. Temkin方程为 $G=A+B \lg C$, 其中 $G$ 为吸附量, $C$ 为 平衡浓度, $A$ 和 $B$ 为两个常数; 以 $G$ 对 $\lg C$ 作图为一条直 线. 表1列出了 Langmuir, Freundlich和Temkin三种吸附 方程拟合的结果. 可以看出, Langmuir吸附模型的线性 相关系数大于 Freundlich 和 Temkin吸附模型的, 说明 $\mathrm{TiHAP}$ 和 $\mathrm{TiO}_{2}$ 粉体对BPA的吸附更符合Langmuir吸附方 程, 吸附热不随吸附而变化, 每一个吸附点的能量不变, 是均匀的表面吸附.

图 5 中回归直线的截距是饱和吸附量 $G^{0}$ 的倒数, 由 此算得 $\mathrm{TiHAP}$ 和 $\mathrm{TiO}_{2}$ 粉体单位表面上达到饱和的最大 吸附量分别为 8.55 和 $0.45 \mathrm{mg} / \mathrm{g}$, TiHAP粉体对 BPA的吸 附能力优于 $\mathrm{TiO}_{2}$ 粉体.

由图4可知, 在 $\mathrm{pH}$ 为 7 左右时, $\mathrm{TiHAP}$ 和 $\mathrm{TiO}_{2}$ 的Zeta 电位值相差不多, 说明表面电荷不是颗粒物吸附性能差 异的原因; 另外, 两者的比表面积和平均孔径相似, 本体 的表面吸附应该也不是主要原因. TiHAP是HAP的金属 取代物, HAP表面的 P-OH基团可部分形成 Ti-OH基 团 ${ }^{[27]}$, 使TiHAP 晶体中含大量磷酸根和羟基, 可以通过 氢键吸附BPA上的羟基, 从而将BPA吸附到TiHAP表面. 虽然P25 $\mathrm{TiO}_{2}$ 表面也有 $\mathrm{Ti}-\mathrm{OH}$ 基团, 但由实验结果可知, $\mathrm{TiHAP}$ 粉体对BPA的吸附能力大于 $\mathrm{TiO}_{2}$ 粉体.

\subsection{TiHAP和 $\mathrm{TiO}_{2}$ 薄膜光催化降解BPA}

\subsection{1. 光催化降解活性}

空白实验表明, BPA在 $\lambda=365 \mathrm{~nm}$ 的紫外光照下不 发生光解; HAP样品在本实验光源下也无催化活性. 由 图3 可知, HAP在 $\lambda<300 \mathrm{~nm}$ 的紫外光照下才能被激发, 所以在本文条件下不具有催化活性. 图6为 TiHAP和 $\mathrm{TiO}_{2}$ 薄膜对BPA溶液的光催化降解曲线. TiHAP薄膜和 $\mathrm{TiO}_{2}$ 薄膜对 BPA的光催化降解速率常数分别为 $0.115 \mathrm{~h}^{-1}$
和 $0.048 \mathrm{~h}^{-1}$, 由此算得, 前者是后者的 2.4 倍.

\subsubsection{FA的影响}

图7为不同FA浓度的溶液中 $\mathrm{TiHAP}$ 和 $\mathrm{TiO}_{2}$ 薄膜光催 化降解BPA的速率常数. 由图可见, 随着FA浓度的增加, TiHAP薄膜光催化降解BPA的速率常数减小, 而 $\mathrm{TiO}_{2}$ 薄 膜的却增加. 推测可能的原因为: FA的LUMO轨道高于 $\mathrm{TiO}_{2}$ 的导带, $\mathrm{FA}$ 受光激发后光生电子能够转移到 $\mathrm{TiO}_{2}$ 的 导带上, 光生电子可以进一步与 $\mathrm{O}_{2}$ 作用形成 $\cdot \mathrm{O}_{2}{ }^{-[28]}$, 进 而提高了BPA的氧化去除效率. TiHAP的带隙很大, 导 带位置很高 ${ }^{[21]}$, FA的光生电子不能转移到TiHAP的导带 上; 相反, TiHAP的光生激子可以转移到FA的基态上, 即FA起到了猝灭TiHAP中激子的作用, 从而降低了其光 催化去除BPA效率. 另一方面, FA可作为光生空穴的捕 获剂, 使光生电子空穴的分离效率增加, 且随FA浓度的 增加分离效率增大.

\subsection{3. $\mathrm{Fe}^{3+}$ 的影响}

图8为在不同 $\mathrm{Fe}^{3+}$ 浓度下 $\mathrm{TiHAP}$ 和 $\mathrm{TiO}_{2}$ 薄膜光催化 降解BPA的反应速率. 可以看出, 随 $\mathrm{Fe}^{3+}$ 浓度的增大, $\mathrm{TiO}_{2}$ 光催化降解BPA的活性逐渐增大. $\mathrm{Fe}^{3+}$ 可捕获光生 电子 ${ }^{[29]}$, 增加了电子空穴的分离效率, 从而使光生空穴 得到更好地利用, 产生更多的活性氧物种如羟基自由基, 进而促进了BPA的氧化降解. 而对于TiHAP, 在低浓度 $\mathrm{Fe}^{3+}$ 存在时, 其催化降解BPA的性能增加; 之后随 $\mathrm{Fe}^{3+}$ 浓 度的增加而降低. 推测可能的原因为: TiHAP表面的光 生电子-空穴对密度较低, 所以低浓度的 $\mathrm{Fe}^{3+}$ 可有助于电 子空穴的分离; 高浓度的 $\mathrm{Fe}^{3+}$ 反而可作为电子空穴的复 合中心, 从而不利于氧化性物质的生成. 另外一个可能 的原因是, TiHAP对 $\lambda=365 \mathrm{~nm}$ 的紫外光吸收较弱, 在 $\mathrm{Fe}^{3+}$ 浓度高时, 溶液颜色加深, 不利于 TiHAP对光的吸 收, 导致其催化活性降低.

\section{4. 结论}

TiHAP和 $\mathrm{TiO}_{2}$ 粉体对BPA的吸附符合Langmuir吸附 等温方程, 同等条件下, TiHAP对BPA的最大吸附量是 $\mathrm{TiO}_{2}$ 的19倍, 这是由于 $\mathrm{BPA}$ 分子的羟基与 $\mathrm{TiHAP}$ 表面的 差基形成氢键所致. TiHAP薄膜光催化降解BPA的一级 反应速率常数是 $\mathrm{TiO}_{2}$ 的 2.4 倍. $\mathrm{TiHAP}$ 的光催化反应机 制还有待于进一步探讨, 提高辐照强度预计会提高其催 化性能. 本结果可为TiHAP降解环境内分泌干扰物提供 依据, 具有一定的理论和应用价值. 